\title{
Findings of Daphnia (Ctenodaphnia) Dybowski et Grochowski (Branchiopoda: Cladocera) in Cenozoic volcanogenic lakes in Germany, with discussion of their indicator value
}

\author{
Alexey A. Kotov and Torsten Wappler
}

\begin{abstract}
The goal of this paper is to describe fossil representatives of the Daphniidae Straus, 1820 (Eucrustacea: Cladocera) from German Cenozoic Maar lakes and lacustrine sediments and discuss an indicator value of their ephippia for palaeoecological reconstructions. All females and ephippia (modified moulting exuvia of females containing resting eggs) from the late Early/early Middle Miocene Randeck Maar (about 17-15 m.y.a., mammal zone MN5) and ephippia from the Late Oligocene lacustrian locality Rott (23-24 m.y.a., mammal zome MP30) belong to Daphnia (Ctenodaphnia) Dybowski et Grochowski, 1895. We conclude that these cladocerans were very common in European Eocene-Miocene water bodies. In case of German volcanogenic Maars, numerous ephippia of Daphnia (Ctenodaphnia), including their clusters, in a fossil layer could indicate shallow water conditions and seasonality in such water body.
\end{abstract}

Alexey A. Kotov. A.N. Severtsov Institute of Ecology and Evolution, Leninsky Prospect 33, Moscow 119071, Russia. alexey-a-kotov@yandex.ru

Torsten Wappler. Steinmann Institute, Section Palaeontology, University of Bonn, Nussallee 8, 53115

Bonn, Germany. twappler@uni-bonn.de

Keywords: Eucrustacea, Cladocera, Tertiary, ephippia, Rott, Randeck Maar

Submission: 17 February, 2015 Acceptance: 15 July 2015

\section{INTRODUCTION}

Ancient Maar lakes and lacustrine sediments are of outstanding importance for the reconstruction of continental palaeoecosystems with high-resolution unique data for palaeoecological and palaeoclimatological research. Unlike marine sediments, lake deposits can provide highly resolved local records or regional developments. These might otherwise be represented by fluvial sedi- ments, which are more likely to preserve transported and time-averaged fossil assemblages (Spicer, 1991; Wappler et al., 2009). Nevertheless, many of those Maar lakes are famous Cenozoic "fossillagerstätten" with well-preserved fossils of different ages: from Eocene, e.g., Messel (Lutz, 1991; Franzen, 2005) and Eckfeld Maar (Lutz et al., 2010), through Oligocene, e.g., Rott (von Heyden, 1862; Petrulevičius et al., 2011) and Enspel (Wuttke et al., 2010), to the Miocene, e.g., Ran-

Kotov, Alexey A. and Wappler, Torsten. 2015. Findings of Daphnia (Ctenodaphnia) Dybowski et Grochowski (Branchiopoda:

Cladocera) in Cenozoic volcanogenic lakes in Germany, with discussion of their indicator value. Palaeontologia Electronica 18.2.40A: $1-9$

palaeo-electronica.org/content/2015/1290-cenozoic-daphnia-from-germany 
deck Maar (Rasser et al., 2013). The spectrum of fossils from these localities includes almost everything from complex organic molecules to articulated mammals with soft tissue preservation (Schaal and Ziegler, 1992; Lutz et al., 2010; Rasser et al., 2013). Among these some fossil groups have an obvious significance for the stratigraphy, ecological and climatic reconstructions, such as mammals (Fejfar et al., 1997; Böhme, 2003) or pollen (Utescher et al., 2000). For other fossil taxa such indicator value is less obvious or unknown. The latter include first of all cladocerans (Crustacea: Branchiopoda) that are known as good indicator for reconstructing of fossil lake communities und understanding of long-term lake dynamics (Frey, 1964; Nevalainen et al., 2011). It is known that they are among the dominant groups in fresh water at least since the Mesozoic (Smirnov, 1992; Kotov and Korovchinsky, 2006; Kotov and Taylor, 2011). They originated in the Palaeozoic (Frey, 1987; Sacherová and Hebert, 2003; Kotov, 2013), but the authors of all papers with descriptions of Palaeozoic cladoceran-like fossils (Smirnov, 1970; Anderson et al., 2004; Womack et al., 2012) did not represent really strong evidences of their belonging to the cladocerans (Kotov, 2013). Only a few papers were published on Palaeogene and Miocene cladocerans (Frey, 1964; Yixin, 1995; Peñalver et al., 1996; Greenwalt et al., 2014; Wappler et al., 2014), in contrast to very numerous publications concerning their remains from Neogene, specially Holocene (Frey, 1964; Rautio, 2007; Nevalainen et al., 2011). At least for some Cenozoic Central European Maar lakes like Messel (Lutz, 1991; Richter and Wedmann, 2005) and Randeck (Heizmann and Schweigert, 1988) or the lacustrine sediments from Rott (von Heyden, 1862; Rolfe, 1963) ephippia of Daphnia were reported, but no adequate descriptions of the fossils were made, nor accurate determinations were provided, and no conclusions on their stratigraphic significance were made.

Our aim was to describe fossil cladocerans from two Cenozoic Maars in Germany (Rott and Randeck) and discuss an indicator value of their ephippia for palaeoecological reconstructions.

\section{MATERIAL AND METHODS}

Material for this study was from two different collections: Steinman Institute, University of Bonn (STIPB) and Staatliches Museum für Naturkunde Stuttgart (SMNS). The specimens were observed and digitized using a Keyence VHX-1000 microscope, and all the structures were measured on the digitized images. Additionally, each specimen was photographed using a Canon EOS 30D camera with a Canon EF-S $60 \mathrm{~mm} \mathrm{f} / 2.8$ macro lens or a Nikon Coolpix E4500. Transmitted light was obtained from a VisiLED ACT Basis (Schott, Stafford, UK).

\section{LOCALITIES AND STRATIGRAPHY}

\section{Randeck Maar}

The Randeck Maar is located in southwest Germany, southeast of Stuttgart at the escarpment of the Swabian Alb $\left(48^{\circ} 71 ' \mathrm{~N}, 9^{\circ} 31.8^{\prime} \mathrm{E}, 750 \mathrm{~m}\right.$ elevation). The Maar deposits consist of volcanoclastic limestones overlain by Miocene sediments (Krautter and Schweigert, 1991), which are dated as Early/Middle Miocene (Burdigalian, Karpatian, MN 5, ca. 16-18 m.y.a., Heizmann, 1983). The age and palaeoenvironment of the Randeck Maar has been briefly summarized in Rasser et al. (2013) and Kotthoff et al. (2011). Studied fragment belongs to the second successive lake stages (sensu Jankowski, 1981), which is interpreted as a brackish and lacustrine-eutrophic lake stage with bituminous laminites (Dysodil, Blätterkohle) in the central part of the lake.

\section{Rott}

The fossiliferous sediments, also known as the "Sapropelite- and Diatomite-Layers," consist of alternating sapropelites, diatomites, radiolarites, bituminous clays and lignite layers reaching a height of 3-5 m. Chronostratigraphically, the sediments belong to the uppermost Late Oligocene, biostratigraphically (according to the mammal fossils) to Zone MP 30 (Mörs, 1995); MP 30 ranges from Subchron C7An to the top of Subchron C6Cn.2r (Agusti et al., 2001). Therefore, the absolute age of the Rott locality is 24-23 m.y.a. (Kempf et al., 1997; Böhme, 2003; Petrulevičius et al., 2011).

\section{RESULTS}

CLADOCERA Latreille, 1829

ANOMOPODA Sars, 1865

DAPHNIIDAE Straus, 1820

DAPHNIA O. F. Müller, 1785

\section{Randeck Maar}

Material. Rock fragment SMNS 101.665 (Figure 1.1-2): 15 complete females and 5 ephippia.

Description. Adult parthenogenetic females with body widely ovoid in lateral view (Figure 1.3-7), dorsal margin regularly and slightly curved, lacking 

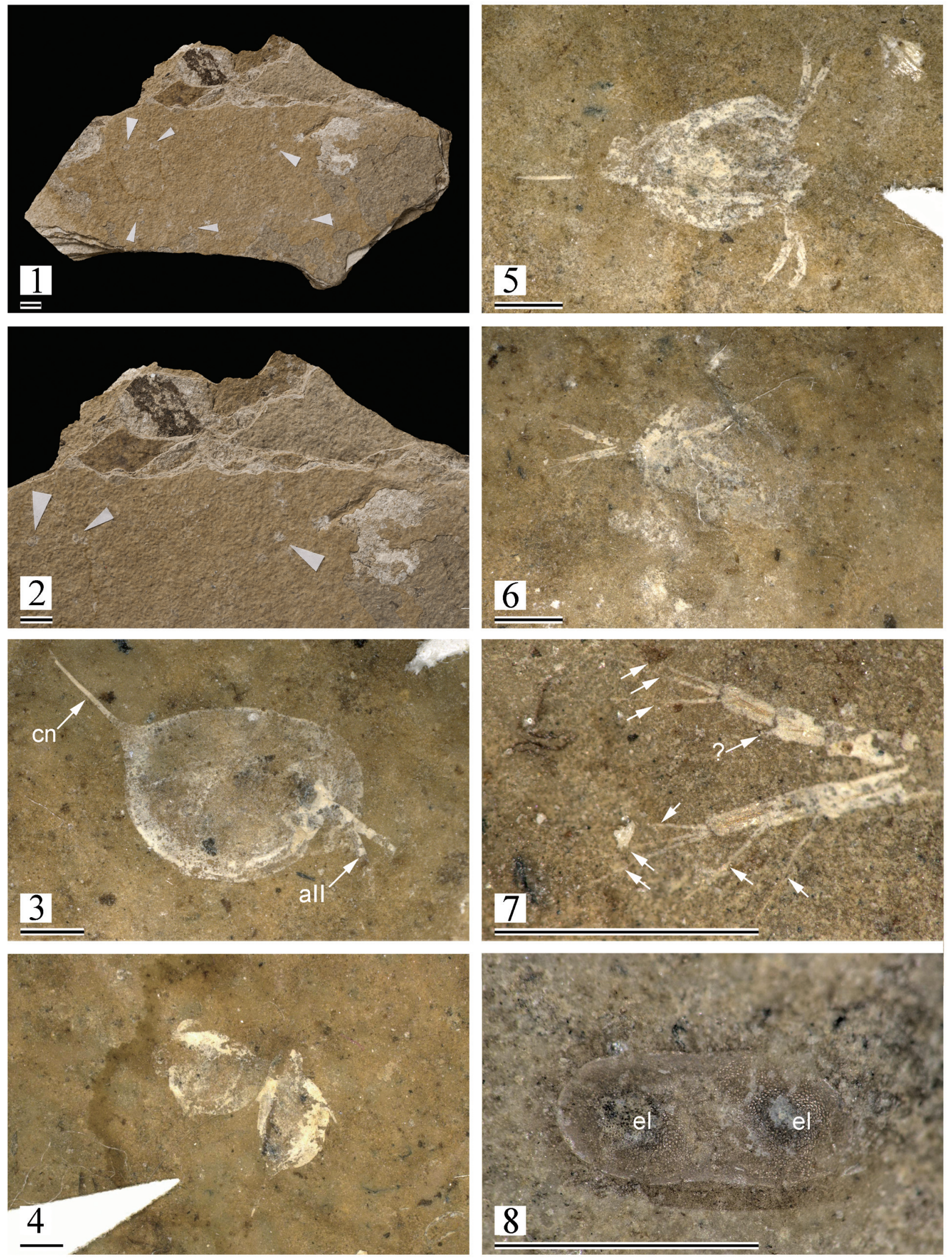

FIGURE 1. Fossils from Randeck Maar, rock fragment, SMNS 101.665: 1 - whole rock fragment with paper arrows pointing out the impressions of Daphnia (Ctenodaphnia) parthenogenetic females in upper (yellowish) layer. 2 - its side portion, with visible alternation of yellowish and grayish layers. 3 - adult female, lateral view. 4 - two females, dorso-lateral view. 5 - dorsal view. 6-7 - lateral view and antenna II. 8 - ephippium in grayish layer. All scales equal 1 $\mathrm{mm}$. Abbreviations: all - antenna II; cn - caudal needle; el - egg loculus. 
any depressions, caudal needle (Figure 1.3: cn) rojected postero-dorsally at angle of approximately $45^{\circ}$ to dorsal margin. In dorsal view body wide, without a head keel. Head small, rectangularovoid, rostrum relatively elongated, length of antenna II (Figure 1.3: all) (without setae) approximately half body length, antennal formula (reflecting number of setae on each segment of exopod/ each segment of exopod from proximal to distal one): setae $0-0-1$ ? -3/1-1-3 (each seta marked by arrow in Figure 1.3.7). Size varies between 2.7 and $3.2 \mathrm{~mm}$ (without caudal needle), and between 3.4 and $4.5 \mathrm{~mm}$ (including caudal needle).

Ephippia with shape in general ovoid (Figure 1.8), caudal needle not incorporated to ephippium, height/length $=0.43-0.46$. Dorsal margin almost straight, ventral margin slightly concave. Egg loculi (Figure 1.8: el) located aslant to dorsal margin, egg loculus length about 0.75 times of ephippium maximum height. Dorsal plate without reticulation, all other surfaces including egg loculi finely tuberculated. Size varies between 0.9 and $1.2 \mathrm{~mm}$.

Comments. Complete females are found on the upper, brownish layer of the rock fragment SMNS 101.665, while ephippia are present on a greyish layer, underlying the former (Figure 1.2), such layers are well-defined parallel rhythmites that vary in thickness from approximately 100 to $500 \mu \mathrm{m}$. Additionally, these layers can vary in thickness relative to one another. If flat imprints represent females, the ephippia kept their three-dimensional structure, which could suggest different conditions at their formation probably associated with different seasons, as in recent daphniids (Dumont and Negrea, 2002; Benzie, 2005).

Both females and ephippia apparently belong to Daphnia O.F. Müller, 1785, more precisely, to Daphnia (Ctenodaphnia) Dybowski and Grochowski, 1895 (see differences between subgenera in Benzie, 2005; Kotov and Taylor, 2011). Among recent species, the females from Randeck Maar are maximally similar to those of $D$. (Ctenodaphnia) magna Straus, 1820 (i.e., in a very small and sub-quadrangular head), while ephippia - to D. (Ctenodaphnia) atkinsoni Baird, 1850 (i.e., by concave ventral margin and fine granulation of surface) (see recent species in Benzie, 2005). If the females and ephippia belong to the same species (which is not obvious, because they were presumably fossilized during different seasons, see below), it is an unknown extinct taxon with unknown biology.

\section{Rott}

Material. Syntypes of Daphnia fossilis von Heyden: STIPB-RO-A-557 (Figure 2.1), four ephippia, label on the rock fragment "Daphnia foss., Pal. X, taf. X, fig. 25," paper label "Daphnia fossilis HEYD., Orig. m. von HEYDEN?, Rott/Siebengebirge."

Other syntypes are present in the collection of Museum of Comparative Zoology, Harvard University, USA, accession number 109470.

Other material (Figure 2.2-8). STIPB-RO-A643a-b: about 30 ephippia. STIPB-RO-A-644a-c: hundreds of ephippia, including a cluster of those on a small stick (Figure 2.3). STIPB-RO-A-646: about 40 ephippia. STIPB-RO-A-647: about 40 ephippia. STIPB-RO-A-648b: presumable complete female (Figure 2.2) and 5 ephippia on face side, 6 ephippia on reverse side. STIPB-RO-A654a-d: hundreds of ephippia, including a cluster of those on a small stick (Figure 2.4).

Description. Ephippium ovoid-elongated to triangular-rounded (Figure 2.5-8), height/length $=0.40$ 0.46 , dorsal margin slightly convex to almost straight, continuing into a fine anterior prominence (Figure 2.5: ap) (lost in some ephippia), posterior most portion narrowing, with rounded posterior most extremity, ventral margin convex, anterior most angled. Two egg loculi (Figure 2.5: el) located at acute angle to dorsal margin, with a gap between each other and between them and dorsal or ventral margin, width of which varies; loculus length $=0.5-0.7$ times ephippium maximum height. Size varies between 1.0 and $1.4 \mathrm{~mm}$.

Comments. The taxon Daphnia fossilis von Heyden, 1862 was described based on ephippia without any adequate explanations of their differences from these of extant taxa (von Heyden, 1862, p. 62-63, plate 10: figure 25). We even cannot finally say, do ephippia of Daphnia (Ctenodaphnia) in Rott palaeolake belong to a single taxon, or to few different taxa? Among extant taxa, ephippia from Rott are maximally similar to those of the $D$. similis $-D$. magna species group sensu Adamowicz et al. (2009), which needs to be revised morphologically.

\section{DISCUSSION}

Our descriptions of representatives of Daphnia (Ctenodaphnia) from two palaeolakes demonstrate once more that these crustaceans were common in European Eocene-Miocene water bodies. The fact that they were previously found only in few other palaeolakes of this time (Peñalver et al., 1996), i.e., in other Tertiary Central European Maar 

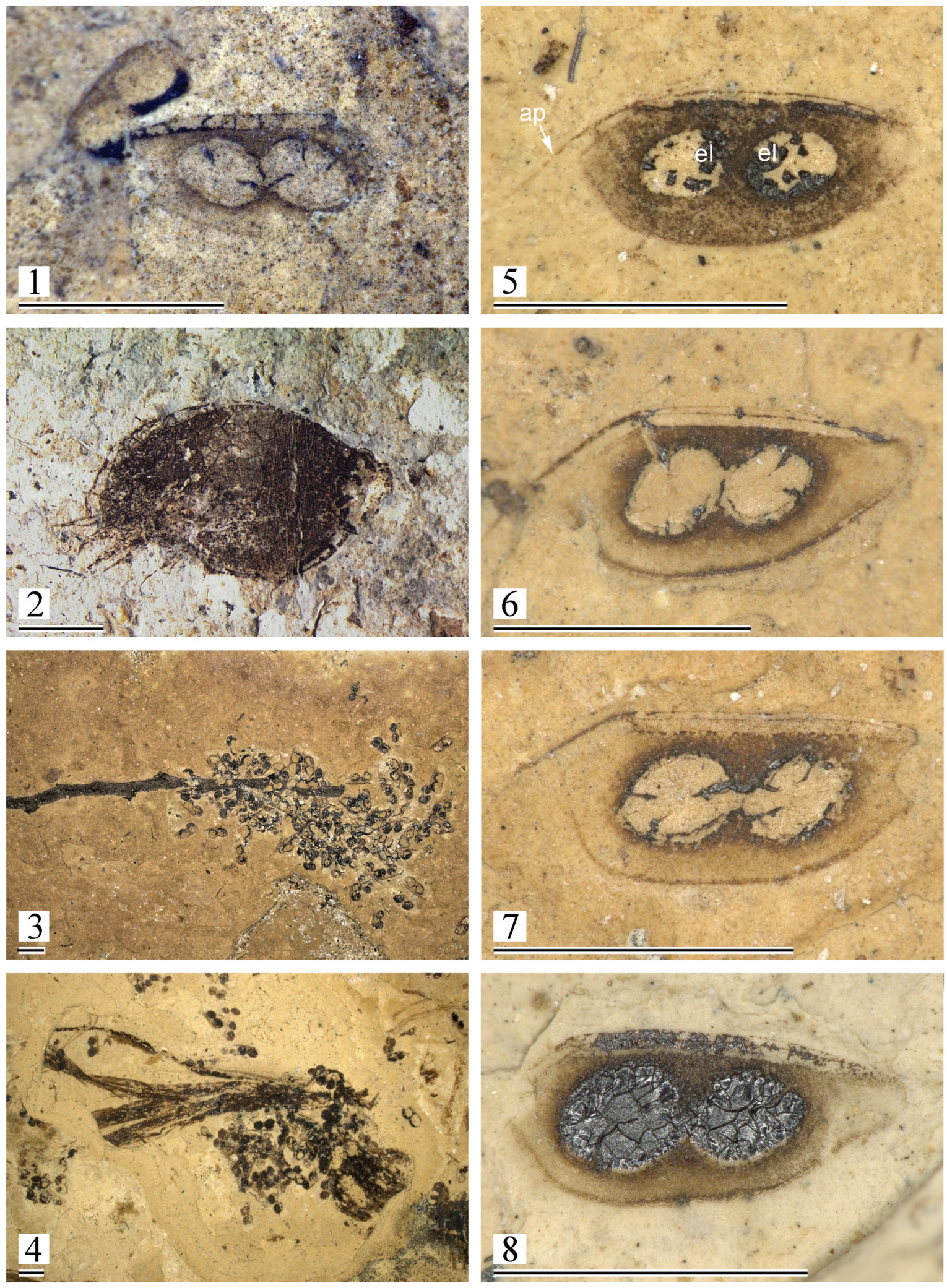

FIGURE 2. Fossils from Rott in the collection of SIUB. 1 - ephippium, syntype of Daphnia fossilis von Heyden, 1862, fragment A557. 2 - presumable adult female, A 648bB. 3-4 - clusters of ephippia attached to small sticks, A654 and A644a. 5-8 - general view of ephippia, A644a, A647 (two), A654b. All scales equal $1 \mathrm{~mm}$. Abbreviations: ap - anterior projection; el - egg loculus. 
lakes (Lutz, 1991; Richter and Wedmann, 2005), could be explained by an insufficient attention of palaeontologists instead of their absence in the lakes during their existence or taphonomic biases. Ephippia of Daphnia are well-preserved and common component of many palaeocommunities (Frey, 1964; Rautio, 2007; Nevalainen et al., 2011). In addition to autochtonous ephippia, they also could be brought to lakes by rivers, spring flooding, etc. from other water bodies in a large number.

Cladocerans are remarkable for their mode of reproduction, a cyclic parthenogenesis (Dumont and Negrea, 2002). As majority of the cladocerans, extant Daphnia reproduce parthenogenetically during most part of the season; only during unfavorable conditions (dry summer in the South, or cold winter in the North) they start the gamogenetic reproduction, resulting in deposition of resting eggs into their resting stages - the ephippia, until more favorable times. Then a population during some time is represented by resting eggs only (in some cases a minority of females is over-wintering), which start to hatch when conditions became more favorable.

At least a part of fresh ephippia of Daphnia are floating on the water surface, dislocated by wind and/or water currents, finally reaching the littoral zone, and become attached to macrophytes and other objects (Pietrzak and Slusarczyk, 2006). Floating ephippia are quite sticky (both due to hydrophobic interactions and presence of special small denticles), and they are frequently attaching to the feathers of landing water birds (being main dispersers of the daphniids), wool of large mammals and even to large insects (Benzie, 2005). At water edge, ephippia could form a wide belt and be massively deposited, and dried. Such ephippia could be dispersed by wind. After few days, still floating ephippia absorb the water, get heavy, and sink. Most ephippia in a large lake systems are initially deposited to the bottom sediments in the littoral zone. The latter peculiarity is important for continuing their life cycle, because hatching of resting eggs is initiated by such environmental stimuli as changes in the light day duration and temperature, which are well-expressed in the littoral zone, but smoothed on the bottom in the deeper portion of a lake (Carvalho and Wolf, 1989). Such peculiarities of the Daphnia life cycle could be important for palaeoecological reconstructions keeping in mind that (1) ephippia are very common in palaeocommunities of different geological age; (2) their mass deposition is clearly associated with certain seasons; (3) some Daphnia species (e.g., D. magna) are model objects of recent evolutionary biology, and their life cycle is well-studies (in comparison with other cladocerans and many other planktonic animals) (Lampert, 2011).

To our mind, there are evidences that ephippia from the Randeck Maar and the lake deposits of Rott were fossilized in shallow portions of the lakes, or even in some small water bodies near the lakes, and their fossilization was associated with specific seasons.

\section{CONCLUSIONS}

Data from this study support five major conclusions. These conclusions warrant further verification from investigations of additional localities to clarify the impact of cladocerans for palaeoecological reconstructions in deep time.

1. All revealed ephippia belong to the subgenus $D$. (Ctenodaphnia), which now occurs predominantly in shallow (mainly temporary) water bodies (although sometimes occur in large lakes too) (Benzie, 2005). Among the subgenus representatives, there are both species tolerant to salinity (like $D$. magna) and exclusively fresh water ones (like $D$. similis), therefore presence of a $D$. (Ctenodaphnia) in the Randeck Maar lake could not be used as indicator of salinity (data that is contradictory for this locality, Rasser et al., 2013). At the same time, in both water bodies we did not find any representatives of another subgenus, Daphnia (Daphnia), which is very characteristic for recent large freshwater lakes (although could also be present in temporary waters and small permanent ponds). Absence of the latter in Rott (the material from Randeck Maar was too scarce for such conclusions) more probably could be explained by some peculiarities of taphonomy instead of real absence of Daphnia (Daphnia) in this palaeolake. It is known that Rott lake was existing during several millions of years (Wappler et al., 2010) and had a strong chance to be colonized by any taxa of $D$. (Daphnia). The latter subgenus is present since the Mesozoic (Kotov and Taylor, 2011) and was found to be common in the Eocene Messel palaeolake (Richer and Wedmann, 2005). Maybe it was also common in Rott, but any ephippia from the pelagic zone were not kept.

2. In Randeck Maar, the impressions of parthenogenetic females and ephippia are apparently associated with different layers. We can 
presumably associate the female fossilization with a summer period, while fossilization of the ephippia with autumn-winter time, which agrees with the cladoceran life cycle.

3. In Rott some rock fragments contain hundreds of ephippia, with a density of 10-30 ephippia per $1 \mathrm{~cm}^{2}$ (or even more in case of clusters, see below). Therefore, we have a chance to speak about a massive production of ephippia in a time before their fossilization (if they are autochtonous, see below about a chance of their allochtonous origin). Keeping in mind the life cycle of recent species, it happened in autumn-winter.

4. In Rott we found several large clusters of ephippia attached to small sticks. It usually happens with extant daphniids in autumn, when they massively produce ephippia, which are floating, being sticky, and attaching to any objects in littoral zone of lakes. In contrast, drowned ephippia are not cyling (first of all, because their surface is already not hydrophobic).

5. Even if the ephippia in Rott are allochtonous, their mass deposition suggests seasonality, because it means that they appeared in the lake during a (spring-earlier summer?) flooding. The chance of fossilization in a shallow portion of a lake is higher because old ephippia are heavier than water and sinking fast, having no chance to reach a deeper part of a lake. But allochtonous scenarios seem to be less realistic because they have to lead to a random distribution of the ephippia. In contrast, the ephippia in Rott demonstrate too high density on some fragments and fully absent on many other fragments.

It is clear that ephippia could be fossilized in a deeper portion of the lakes. In this case, we cannot speak about any seasonality. Ephippia are quite firm, and they could not be destroyed by an aggressive environment during a short time (within a season). But in case of German volcanogenic Maars (like Randeck Maar and Rott), numerous ephippia, including their clusters, in a fossil layer could indicate shallow water conditions and seasonality in such water body. But only rock fragments with numerous ephippia could be used for such conclusions.

\section{ACKNOWLEDGEMENTS}

We are grateful to Prof. N.N. Smirnov for valuable discussions and Dr. J.D. Cundiff for informa- tion on type material in the Museum of Comparative Zoology, Harvard University. The study was supported by the Russian Science Foundation (grant 14-14-00778).

\section{REFERENCES}

Adamowicz, S.J., Petrusek, A., Colbourne, J.K., Hebert, P.D.N., and Witt, J.D.S. 2009. The scale of divergence: a phylogenetic appraisal of intercontinental allopatric speciation in a passively dispersed freshwater zooplankton genus. Molecular Phylogenetics and Evolution, 50:423-436.

Agusti, J., Cabrera, L., Garcés, M., Krijgsman, W., Oms, O., and Parés, J.M. 2001. A calibrated mammal scale for the Neogene of Western Europe. State of the art. Earth Science Reviews, 52:247-260.

Anderson, L.I., Crichton, W.R.B., and Hass, H. 2004. A new univalve crustacean from the Early Devonian Rhynie chert hot-spring complex. Transactions of the Royal Society of Edinburgh: Earth Sciences, 94:355369.

Baird, W. 1850. Descriptions of several new species of Entomostraca. Proceedings of the Zoological Society of London, 18:254-257.

Benzie, J.A.H. 2005. The genus Daphnia (including Daphniopsis) (Anomopoda: Daphniidae). (Guides to the identification of the microinvertebrates of the continental waters of the world 21). Kenobi Productions, Ghent and Backhuys Publishers, Leiden.

Böhme, M. 2003. The Miocene climatic optimum: evidence from ectothermic vertebrates of Central Europe. Palaeogeography, Palaeoclimatology, Palaeoecology, 195:389-401.

Carvalho, G.R. and Wolf, H.G. 1989. Resting eggs of lake-Daphnia.1. Distribution, abundance and hatching of eggs collected from various depths in lake sediments. Freshwater Biology, 22:459-470.

Dybowski, B. and Grochowski, M. 1895. Spis systematyczny wioślarek (Cladocera) krajowych. Kosmos, 20:139-165.

Dumont, H.J. and Negrea, S.V. 2002. Introduction to the class Branchiopoda. (Guides to the identification of the microinvertebrates of the continental waters of the world 19). Backhuys Publishers, Leiden.

Fejfar, O., Heinrich, W.-D., Pevnzer, M.A., and Vangengeim, E.A. 1997. Late Cenozoic sequences of mammalian sites in Eurasia: an updated correlation. Palaeogeography, Palaeoclimatology, Palaeoecology, 133:259-288.

Franzen, J.L. 2005. The implications of the numerical dating of the Messel fossil deposit (Eocene, Germany) for mammalian biochronology. Annales de Paleontologie, 91:329-335.

Frey, D.G. 1964. Remains of animals in Quaternary lake and bog sediments and their interpretation. Ergebnisse der Limnologie, 2(1):1-114.

Frey, D.G. 1987. The taxonomy and biogeography of the Cladocera. Hydrobiologia, 145:5-17. 
Greenwalt, D., Rose, T., Siljestrom, S., Goreva, Y., Constenius, K., and Wingerath, J., 2014. Taphonomic studies of the fossil insects of the Middle Eocene Kishenehn Formation. Acta Palaeontol Polonica, Doi: 10.4202/app.00071.2014

Heizmann, E.P.J. 1983. Die Gattung Cainotherium (Cainotheriidae) im Orleanium und im Astaracium Süddeutschlands. Eclogae Geologicae Helvetiae, 76:781-825.

Heizmann, P.J. and Schwieger, G. 1988. Das Randecker Maar. Ein miozäner Kratersee am Drauf der Schwäbischen Alb, p. 204-214. In Weidert, W.K. (ed.), Klassische Fundstellen der Paläontologie: 22 Fundgebiete und Aufschlusse in Dänemark, Deutschland, Frankreich, Österreich, Schweden, Schweiz und Tschechien. Vol. 4. Goldschneck-Verlag, Korb.

Jankowski, B. 1981. Die Geschichte der Sedimentation im Nördlinger Ries und Randecker Maar. Bochumer Geologische und Geotechnische Arbeiten, 6:1-315.

Kempf, O., Bollinger, T., Kälin, D., Engesser, B., and Matter, A. 1997. New magnetostratigraphic calibration of Early to Middle Miocene mammal biozones of the North Alpine Foreland Basin. Mèmoires et Travaux E.P.H.E., Institut de Montpellier, 21:547-561.

Kotov, A.A. 2013. Morphology and phylogeny of the Anomopoda (Crustacea: Cladocera). KMK Press, Moscow.

Kotov, A.A. and Korovchinsky, N.M. 2006. First record of fossil Mesozoic Ctenopoda (Crustacea, Cladocera). Zoological Journal of the Linnean Society, 146:269274.

Kotov, A.A. and Taylor, D.J. 2011. Mesozoic fossils (>145 Mya) suggest the antiquity of the subgenera of Daphnia and their coevolution with chaoborid predators. BMC Evolutionary Biology, 11:129.

Kotthoff, U., Wappler, T., and Engel, M.S. 2011. Miocene honey bees from the Randeck Maar of southwestern Germany (Hymenoptera, Apidae). ZooKeys, 96:1137.

Krautter, M. and Schweigert, G. 1991. Bemerkungen zur Sedimentation, Flora und dem Paläoklima des Randecker Maars (Unter-/Mittel-Miozän, Schwäbische Alb). Neues Jahrbuch für Geologie und Paläontologie, Monatshefte, 1991:505-514.

Lampert, W. 2011. Daphnia: development of a model organism in ecology and evolution. Excellence in Ecology, 21:1-250.

Latreille, P.A. 1829. Les Crustacés, les Arachnides et les Insectes, distributes en Families Naturelles. Déterville, Paris.

Lutz, H. 1991. Autochthone aquatische Arthropoda aus dem Mittel-Eozän der Fundstätte Messel (Insecta: Heteroptera; Coleoptera; cf. Diptera-Nematocera; Crustacea: Cladocera). Courier Forschungsinstitut Senckenberg, 139:119-125.

Lutz, H., Kaulfuß, U., Wappler, T., Löhnertz, W., Wilde, V., Mertz, D.F., Mingram, J., Franzen, J.L., Frankenhäuser, H., and Koziol, M. 2010. Eckfeld Maar: Win- dow into an Eocene terrestrial habitat in Central Europe. Acta Geologica Sinica, 84:984-1009.

Mörs, T. 1995. Die Sedimentationsgeschichte der Fossillagerstätte Rott und ihre Altereinstufung anhand neuer Säugetierfunde (Oberoligozän, Rheinland). Courier Forschungsinstitut Senckenberg, 187:1-129.

Müller, O.F. 1785. Entomostraca seu Insecta Testacea, quae in aquis Daniae et Norvegiae reperit, descripsit et iconibus illustravit. Symtibus Bibliopolii J.G. Mülleriani, Lipsiae et Havniae (Leipzig and Copenhagen).

Nevalainen, L., Luoto, T.P., Kultti, S., and Sarmaja-Korjonen, K. 2011. Do subfossil Cladocera and chydorid ephippia disentangle Holocene climate trends? The Holocene, 22:291-299.

Peñalver, E., Martínez-Delclòs, X., and De Renzi, M. 1996. Registro de pulgas de agua [Cladocera: Daphniidae: Daphnia (Ctenodaphnia)] en el Mioceno de Rubielos de Mora (Teruel, España). Comunicaciones de la II Reunión de Tafonomía y Fosilización, Zaragoza: 311-317.

Petrulevičius, J.F., Wappler, T., Nel, A., and Rust, J. 2011. The diversity of Odonata and their endophytic ovipositions from the Upper Oligocene Fossillagerstätte of Rott (Rhineland, Germany). ZooKeys, 130:67-89.

Pietrzak, B. and Slusarczyk, M. 2006. The fate of the ephippia - Daphnia dispersal in time and space. Polish Journal of Ecology, 54:709-714.

Rasser, M.W., Bechly, G., Böttcher, R., Ebner, M., Heizmann, E.P.J., Höltke, O., Joachim, C., Kern, A.K., Kovar-Eder, J., Nebelsick, J.H., Roth-Nebelsick, A., Schoch, R.R, Schweigert, G., and Ziegler, R. 2013. The Randeck Maar: Palaeoenvironment and habitat differentiation of a Miocene lacustrine system. Palaeogeography, Palaeoclimatology, Palaeoecology, 392:426-453.

Rautio, M. 2007. The use of Cladocera in paleolimnology, p. 2031-2039. In Elias, SA (ed.), Encyclopedia of Quaternary Sciences. Elsevier, London.

Richter, G. and Weidmann, S. 2005. Ecology of the Eocene Lake Mesel revealed by analysis of small fish coprolites and sediments from a drilling core. Palaeogeography, Palaeoclimatology, Palaeoecology, 223:147-161.

Rolfe, W.D.I. 1963. Catalogue of type specimens in the invertebrate paleontological collections of the Museum of Comparative Zoology: Arthropoda (Trilobita, Arachnida and Insecta excluded). Bulletin of the Museum of Comparative Zoology at Harvard University, 129:369-398.

Sacherová, V. and Hebert, P.D.N. 2003. The evolutionary history of the Chydoridae (Crustacea: Cladocera). Biological Journal of the Linnean Society, 79:629-643.

Sars, G.O., 1865. Norges ferskvandskrebsdyr. Første Afsnit. Branchiopoda. 1. Cladocera Ctenopoda (fam. Sididae \& Holopedidae). Brøgger \& Christie's Bogtrykkeri, Christiania (Oslo). 
Schaal, S. and Ziegler, W. 1992. Messel. An insight into the history of life and of the Earth. Clarendon Press, Oxford.

Smirnov, N.N. 1970. Cladocera (Crustacea) of Permian deposits from Eastern Kazakhstan. Paleontologicheskiy Zhurnal, 3:95-100.

Smirnov, N.N. 1992. Mesozoic Anomopoda (Crustacea) from Mongolia. Zoological Journal of the Linnean Society, 104:97-116.

Spicer, R.A. 1991. Plant Taphonomic Processes, pp. 71113. In Briggs, D.E.G. and Allison, P. (eds.), Taphonomy: Releasing the data locked in the fossil record. Plenum Press, New York.

Straus, H.E. 1820. Mémoire sur les Daphnia de la classe des Crustacés (seconde partie). Memoires $d u$ Museum D'Histoire Naturelle, 6:149-162.

Utescher, T., Mosbrugger, V., and Ashraf, A.R. 2000. Terrestrial climate evolution in northwest Germany over the last 25 million years. Palaios, 15:430-449.

von Heyden, C. 1862. Gliederthiere aus der Braunkohle des Niederrhein's, der Wetterau und der Rohn. Palaeontographica, 10:62-82.

Wappler, T. 2010. Insect herbivory close to the Oligocene-Miocene transition - a quantitative analysis Palaeogeography, Palaeoclimatology, Palaeoecology, 292:540-550.
Wappler, T., Currano, E.D., Wilf, P., Rust, J., and Labandeira, C.C. 2009. No post-Cretaceous ecosystem depression in European forests? Rich insect-feeding damage on diverse middle Palaeocene plants, Menat, France. Proceedings of the Royal Society B: Biological Sciences, 276:4271-4277.

Wappler, T., Grímsson, F., Wang, B., Nel, A., Ólafsson, E., Kotov, A.A., Davis, S.R., and Engel, M.S. 2014. Before the 'Big Chill': A preliminary overview of arthropods from the middle Miocene of Iceland (Insecta, Crustacea). Palaeogeography, Palaeoclimatology, Palaeoecology, 401:1-12.

Womack, T., Slater, B.J., Stevens, L.G., Anderson, L.I., and Hilton, J. 2012. First cladoceran fossils from the Carboniferous: Palaeoenvironmental and evolutionary implications. Palaeogeography, Palaeoclimatology, Palaeoecology, 344-345:39-48.

Wuttke, M., Uhl, D., and Schindler, T. 2010. The FossilLagerstätte Enspel - exceptional preservation in an Upper Oligocene Maar. Palaeobiodiversity and Palaeoenvironments, 1:1-2.

Yixin, S. 1995. Discovery of resting egg fossils of Cladocera in Anjihai River Formation, Kuitun river section, Jungar Basin and its geological significance. Acta Micropalaeontologica Sinica, 12:63-66. 